\title{
Curriculum Based On Local Wisdom In "Indonesian Food" Course For Prospective Professional Cooks
}

\author{
Rina Rifqie Mariana1 ${ }^{1}$, Siti Zubaidah ${ }^{2}$, Nunung Nurjanah ${ }^{3}$ \\ ${ }^{1}$ Culinary Education Study Program, Universitas Negeri Malang. Semarang 5 Malang, East Java, Indonesia \\ ${ }^{2}$ Department of Biology, Universitas Negeri Malang. Malang, Semarang 5, East Java, Indonesia \\ ${ }^{3}$ Culinary Education Study Program, Universitas Negeri Malang. Semarang 5 Malang, East Java, Indonesia
}

\begin{abstract}
:
This study aims to identify and study the curriculum tools for the Culinary Diploma program which concerns the profile of graduates, materials and teaching methods of "Indonesian food", the expertise of supervisory lecturers in terms of educational background, training and work experience to prepare graduates to become graduates. a professional "Indonesian food" cook. The method used is descriptive qualitative, with the research object of 6 Diploma 3 Catering programs in LPTKs in Indonesia. The results showed that each research indicator was not in accordance with the regulations stipulated in the Vocational Curriculum Preparation Guidelines so that it was unable to produce professional "Indonesian Food" cooks, so it was necessary to review the curriculum content, especially for the content of the course "Indonesian food" both concerning the content. , time, and learning methods.
\end{abstract}

Keyword: curriculum, local wisdom, Indonesian food, cook

\section{Introduction}

Several countries that have a culinary industry that has advanced to the international level have the power to promote their country's original cuisine. Thailand has the same variety of traditional culinary as Indonesia. The support of the Thai government is one of the main supporters that makes Thailand able to develop its culinary abroad. There are already many Thai restaurants spread across Europe, America, and even in Indonesia. According to (Lazuardi \& Triadi, 2015) The Thai government held a Thai kitchen To The Word program, a movement to promote Thai cuisine in the eyes of the world which is being intensively carried out by hotels and restaurants in Thailand. This program enables hotels and restaurants in Thailand to be able to offer quality and world standard traditional culinary delights. This is what has not been done in Indonesia, because there are still many star hotels and restaurants in Indonesia that emphasize foreign culinary delights, even though most of the hotel guests come from abroad. This condition should be used as an opportunity to popularize Indonesian dishes in the eyes of the world.

34 provinces in Indonesia, including the city of Malang, East Java, have regional characteristics of food that have unique flavors and have different characters from one region to another. One of the sources of uniqueness is local specialties. According to the decision of the revitalization workshop of the Center for the Study of Traditional Food in Yogyakarta (2003) (Harmayani et al., 2019), it has been agreed that the boundaries of traditional Indonesian food are food made from ingredients produced in the local community, then processed by means or technology controlled by the people. It can even become the identity of the community group. The "distinctiveness" of regional food has great potential to become one of the driving sectors in realizing the "wealth of the nation" which should be maintained and developed. In line with the era of globalization where foreign cultures easily enter and develop in Indonesia. If it is neglected, it is very possible that the ancestral culture that should be preserved will be displaced, and the people will be 
forgotten more and more. The opportunity for "Indonesian food" to penetrate the international market is very high. Like rendang, fried rice and satay which are declared the most delicious food in the world based on the CNN version. This is what needs to be continuously developed, and continues to create creative ways to develop Indonesian culinary without losing its original taste.

To produce delicious and quality food, of course, requires cooks who are reliable and have creativity, supported by culinary knowledge and practical experience through training and other experiences. Of course, this condition requires the availability of competent, productive and creative human resources (HR) to develop competitive culinary products. Regarding the provision of human resources, it cannot be separated from the role of educational institutions, as one of the national education instruments which are expected to become the center for the implementation and development of higher education and can produce graduates who are able to answer the needs of educated and professional workforce as required by the labor market. As explained by Lazuardi (2015). Theoretically, education is something that cannot be separated, especially in the culinary field. Because education plays a role as a means of creating creative people in the culinary industry, especially the culinary specialties of their own country, namely "Indonesian food". So the hope is that whenever "Indonesian Food" can still occupy the first position in the country and not be less competitive with foreign dishes. Related to culinary education that can be used as a reference is the city of Chengdu, which is in China's Sichuan province, which has been named the world's creative gastronomic city which is recognized by UNESCO as being able to bring traditional Sichuan culinary to international standards and quality (Lazuardi; 2015). The culinary character possessed by the city of Chengdu because of its unique culinary culture, is able to explore the local potential in developing culture with a touch of creativity and expertise from reliable and skilled chefs in processing traditional food. Even the creative idea for the city of Chengdu is to combine local food with theater, other local works of art so that local food is increasingly recognized and loved by the people (Yi, 2016). Furthermore (Lazuardi \& Triadi, 2015) explained that in the city of Chengdu there are 2000 super chefs and 300 national masterchef people who are traditional food experts. One of the Chinese universities that focuses on culinary arts education and research, the Sichuan Higher Institute of Cuisine, is in this city. Chengdu also has the Sichuan Cuisine Museum which displays more than 3,000 kinds of collections about traditional foods, from the most ancient to the most modern and their creations. It means that the development of traditional culinary shows that Chinese culture is a "product of education", both formal and non-formal education. As explained by (Byrnes et al., 2015) in his research, it was stated that the education of a chef, both formally and informally, affects his sensitivity in reacting and assessing quality food in terms of aroma, texture, and food color.

In 2015 - 2016 the city of Malang had prepared itself to propose the world Gatronomy creative city to UNESCO. There are 8 main criteria to be able to submit a proposal to get the nickname of a gastronomic creative city. (Pearson \& Pearson, 2016) in the Gastronomy booklet explains that an area that wants to propose as a gastronomic creative city must have the following criteria, namely 1) the development of culinary delights that represent the character of the city / region, 2) Many reliable and professional cooks in restaurants traditional, 3) endogenous elements (raw materials) are widely used in traditional cooking, 4) The community has knowledge and practices of traditional gastronomy and cooking methods that will sustain the gastronomic industry itself, 5) availability of traditional food markets and traditional food industries, 6) has a 
tradition of organizing gastronomic festivals, awards, contests and recognition from a broad target audience, 7) respecting the environment and introducing sustainable local products, and 8) maintaining public appreciation, introducing traditional food preservation to educational institutions including diversity conservation programs. yati in the culinary curriculum in formal and non-formal educational institutions. Based on research (Mariana et al., 2018) Malang City, which can present other big cities in Indonesia, already has several of the criteria mentioned above. However, one of the prominent weaknesses is that the skills and creativity in processing archipelago cuisine that are owned by the cooks in the hotel / restaurant "Indonesian Food" are still lacking. The young chefs who have a culinary background in the city of Malang generally have more mastery over "oriental food" and "western food" compared to their expertise in Indonesian processing. This is supported by conditions in the field, from 12 restaurants with 177 Indonesian food cooks in Malang, there are $112(63.3 \%)$ with non-linear educational backgrounds (not from culinary schools). Most cooks are between 45 - 55 years old $(44.01 \%)$, and the rest are between 19 - 45 years old. This means that the expertise in processing Indonesian dishes is dominated by those who are elderly where their expertise is obtained from work experience and legacy of parents, and not because of a complete "educational product". If this is not resolved immediately, there is a chance that one day traditional food that reflects the nation's culture will slowly disappear and be displaced by foreign dishes that are increasingly being liked, especially by teenagers in Indonesia. Such conditions are clearly not in line with the ministry of tourism's program (Anggraini, 2018) which will place Indonesia's traditional culinary delights in first place in their own country. So one effort that can be done is to study the culinary field curriculum and its implementation in schools or higher education.

In Indonesia, vocational education (Diploma program) can prepare professional staff, as stated in the Higher Education Law (UUPT) No.12 of 2012 article 16 paragraph 1 , the concept of vocational education is to prepare students to become professionals with high work skills / abilities. The vocational education curriculum is prepared together with the professional community and professional organizations that are responsible for the quality of their professional services so that they meet the requirements of professional competence.

According to (Triyono, 2017), vocational education has characteristics or peculiarities and prioritizes applying practical aspects supported by proper theory. This is to distinguish between academic education which prioritizes theoretical achievements supported by practical aspects. In the Law on the national education system article 15 of 2003 (Nasional et al., 2003) also explains that the purpose of implementing vocational education is to equip and prepare students to be ready to enter the world of work according to their expertise.

However, research (Hanafi, 2012) explains that many vocational / diploma education graduates do not get a job after graduating from college, because they do not have enough skills according to industry needs. In operational practice, one of the achievements of the educational function is inseparable from the curriculum that is presented. Among the most important steps in the curriculum are the steps in implementing it. Curriculum implementation is the process of applying ideas, concepts, policies, innovation, and creativity in a practical action so that it can give good results in the form of changes in terms of cognitive (knowledge), psychomotor (skills), and affective (attitudes) that students have. Often the failure of an applied education policy is not due to inappropriate policies, but 
inaccuracies in implementing them. Like the culinary field Diploma program, one of which is prepared to become a food manager (independent entrepreneur), a supervisor in the culinary sector, and to become a cook, especially for "Indonesian food" in hotels, restaurants, catering, and hospitals. Only the problem is whether the institution through the presented curriculum is able to prepare its graduates to become professionals who are ready to work in the culinary industry. Because after all the results of education will determine the quality of human resources and the enthusiasm of the cooks to maintain and continue to be creative in developing "Indonesian culinary" so that it can last forever, even penetrate the international market. Because basically Indonesia has enormous potential to have high competitiveness. Indonesia has a variety of distinctive and unique traditional culinary delights in each region. Almost all studies in the field of tourism and culinary agree that the curriculum for teaching culinary creativity must cover a variety of creative thinking tasks, and apply a curriculum based on local wisdom, which can be applied to the "Indonesian food" course which has a variety and different culinary characteristics in each. area.

The local content curriculum aims to develop graduates' understanding of the diversity of local cultures and their environment (Musanna, 2010), in addition to that, so that their expertise in processing "Indonesian food" can be deeper and focus on superior dishes in their own regions. Therefore vocational education, more specifically the culinary diploma program, has an obligation to develop strategies through a reliable curriculum so that the capabilities of graduates can be achieved optimally according to the target job market.

Based on these conditions, the specific objective of this research is to identify and study the curriculum tools for the Culinary Diploma program (culinary) related to the development of traditional Indonesian culinary. Of course this must be supported by expertise, professionalism, mastery and creativity in developing the material "Indonesian food". The lecturer supervisors of these courses are based on formal, nonformal education, training, and work experience to prepare prospective "Indonesian Food" cooks who are professional. Because one of the problems, the sinking image of "Indonesian food" is thought to be due to the culinary curriculum (Tata Boga) in Indonesia, which is not able to deliver graduates to have expertise in accordance with industry demands as stated in the purpose of vocational education. The urgency of this research is expected to have an impact on curriculum developers in the field of culinary expertise as input when revitalizing the curriculum or reviewing specific content for the course "Indonesian food". At the same time, it can be implemented through learning through appropriate methods to prepare and produce a professional "Indonesian food" cook to support Indonesian "Gastronomy".

\section{Method}

This research was conducted using a descriptive qualitative approach with a case study design to describe the local wisdombased curriculum in the "Indonesian Food" course for prospective professional cooks in 6 Educational Personnel Education Institutions (LPTK) in Indonesia out of 11 LPTKs that still have Diploma programs. 3 Culinary services, namely: University of Surabaya (UNESA / A1), State University of Malang (UM / A2), Yogyakarta State University (UNY / A3), Jakarta State University (UNJ / A4) Makassar State University (UNM / A5), and Negeri Padang (UNP / A6). 6 The LPTKs that are the objects of the above research are universities that have undergone a change in function from the Teacher Training and Education Institute (IKIP) which originally prepared educators (teachers), then in 2000 they changed their function to become universities that also prepare their graduates 
to become professionals. The stages of the research carried out were as follows: The first stage conducted a review of the curriculum for the Diploma 3 Catering program which included: graduate profiles, Learning Implementation Plans (RPP) specifically for the "Indonesian Food" course, identifying the content of the "Indonesian food" course, which concerns the material, learning resources, and methods used are supported by making direct observations in the field when students do practicum in the laboratory. The second stage, filling out a questionnaire for 6 lecturers who teach the "Indonesian food" course at the 6 institutions above to explore information on the expertise of supervisors based on educational background, training that has been attended, and work experience. The third stage, conducting a Group Discussion Forum (FGD) with 6 coordinators of the LPTK Catering Diploma program in Indonesia, 6 supervisory lecturers for the "Indonesian food" course, 6 industry players from the Indonesian Chef Association (ICA) professional "Indonesia food", and alumni Catering Diploma Program. To discuss the curriculum and its tools and design the concept of curriculum revitalization for the Culinary Diploma Program to develop a "signature culinery through the" Indonesian Food "course. Furthermore, the data that has been obtained is analyzed through three techniques, namely data reduction, data presentation, and verification so that the data obtained can be easily understood and its truth is accounted for.

\section{Result}

Vocational higher education (Diploma program) has a strategic role and is at the forefront of handling the age of the workforce and producing graduates to become skilled, professional and highly competitive workers to increase the nation's competitiveness. Vocational higher education is prepared to produce skilled and trained workforce needed by the industrial world or the world of work that is ready to use and not ready to train. Based on the results of a review of curriculum documents in 6 LPTK diploma 3 culinary programs, it is relevant to the National context and Law Number 12 of 2012 Article 35 paragraph 2 (Number, 12) regarding the education curriculum which refers to the National Higher Education Standards for each Study Program includes the development of intellectual intelligence, noble character, and skills. The curriculum preparation system has referred to Permenristekdikti Number 44 of 2015 concerning the National Higher Education Standards (SNDIKTI). The location of the difference is the substance or content which is the specificity of the curriculum developed by each LPTK.

Based on the results of the study, the culinary / culinary diploma program at 6 universities (LPTK) in Indonesia is as follows:

1. Profiles of graduates of the Diploma 3 Catering program.

The profiles of graduates are oriented towards the profession and world of work, can be seen in the following table.

\begin{tabular}{|c|c|c|c|c|c|}
\hline A1 & A 2 & A 3 & A 4 & A 5 & A 6 \\
\hline $\begin{array}{l}\text { The chef at } \\
\text { HOREKA } \\
\text { Independent } \\
\text { entrepreneur } \\
\text { in the food } \\
\text { industry } \\
\text { Indonesian } \\
\text { cake and }\end{array}$ & $\begin{array}{l}\text { Chefs in } \\
\text { restaurants, } \\
\text { catering, } \\
\text { industrial } \\
\text { food } \\
\text { Culinary } \\
\text { supervisor }\end{array}$ & $\begin{array}{l}\text { Culinary } \\
\text { developer } \\
\text { designer } \\
\text { Food industry } \\
\text { manager } \\
\text { Independent } \\
\text { entrepreneur } \\
\text { in catering }\end{array}$ & $\begin{array}{l}\text { cooks in } \\
\text { hotels, } \\
\text { restaurants, } \\
\text { catering and } \\
\text { cake shop } \\
\text { Cooking } \\
\text { demonstrator } \\
\text { Food stylist }\end{array}$ & $\begin{array}{l}\text { Cooks in } \\
\text { hotels and } \\
\text { restaurants } \\
\text { Self- } \\
\text { employed } \\
\text { entrepreneu } \\
\mathrm{r}\end{array}$ & $\begin{array}{l}\text { Cooks in } \\
\text { hotels, } \\
\text { restaurants } \\
\text { and hospitals } \\
\text { Culinary } \\
\text { supervisor }\end{array}$ \\
\hline
\end{tabular}




\begin{tabular}{|l|l|l|l|l|l|}
\hline $\begin{array}{l}\text { beverage } \\
\text { manager }\end{array}$ & $\begin{array}{l}\text { Self- } \\
\text { employed } \\
\text { catering } \\
\text { services, food } \\
\text { industry }\end{array}$ & $\begin{array}{l}\text { Journalist and } \\
\text { food writer } \\
\text { recipe creator }\end{array}$ & $\begin{array}{l}\text { recipe } \\
\text { creator }\end{array}$ & $\begin{array}{l}\text { Self- } \\
\text { employed } \\
\text { entrepreneur. }\end{array}$ \\
\hline
\end{tabular}

The graduate profile is evidence of the academic accountability of the study program. The characteristics and peculiarities of vocational education graduates must appear on the profile of graduates. As illustrated in table 1, the profiles of graduates in 6 tertiary institutions in Indonesia have similarities in preparing their graduates, namely to 1) become a cook in hotels and restaurants although it is not explicitly mentioned as a cook for "western food", "oriental food" or " Indonesian food ". However, in line with the concept of "local-based curriculum", Indonesian food is a subject that should have a greater proportion than "western food and oriental food". As stated in the Vocational Education Guidelines (Research \& Higher Education, n.d.), the orientation of the profile of vocational higher education graduates must include the posture of a "job creator" who is "aware" and "understands" of their own regional excellence. 2) Independent entrepreneur in the culinary sector. Preparing a diploma program graduate as an entrepreneur is the right step. In accordance with what is contained in (Research \& Higher, N.D.). Several studies, which agree to change the direction of higher education policies from high Learning Institute and Research University to Entrepreneurial University are (Ndou et al., 2019), (Rauch \& Hulsink, 2015) stated that student entrepreneurship education can not only be the main link in the chain. social development and social innovation but can promote innovation and create job opportunities. Developing a business spirit in universities, especially in the vocational field, is an important problem when facing global competition (Scarpetta et al., 2012). Because vocational higher education graduates are required to work competently but must have entrepreneurial abilities. At the vocational higher education level, graduates must also become a "trend setter" in responding to various aspects of the nation's challenges, especially in the culinary field.

\section{Semester Learning Plan (RPS)}

RPS is a learning process plan that is prepared for learning activities for one semester in order to meet the learning outcomes charged on these courses. RPS is determined and developed by lecturers independently or in groups. expertise in a field of science and / or technology in the study program.). Based on a study of the RPS for the "Indonesian food" course developed by the D3 Catering program at 6 LPTKs

the developed system has referred to the Vocational Curriculum Development Guidelines (Research \& Higher Education, N.D.). What distinguishes is the content and substance of the material developed from the start of the development of learning outcomes of "Indonesia food" which of course affects the determination of learning materials, learning methods, timing of each material, the percentage of theoretical and practical lectures, including the references used.

Some of the differences in the substance of the course material "Indonesian food" can be described in the following discussion.

Table 2: Description of "Indonesian Food" Subject Materials, and Practicum Material Sources

\begin{tabular}{|l|l|l|l|}
\hline & $\begin{array}{l}\text { Course Name } \\
\text { Number of credits }\end{array}$ & "Indonesian Food" course material & $\begin{array}{l}\text { Source } \\
\text { practicum material }\end{array}$ \\
\hline
\end{tabular}




\begin{tabular}{|c|c|c|c|}
\hline A1 & $\begin{array}{l}\text { Indonesian } \\
\text { Cuisine ( } 3 \text { credits) }\end{array}$ & $\begin{array}{l}\text { Theory: The character of Indonesian dishes, } \\
\text { the concept of eating patterns in Indonesia, the } \\
\text { concept of Indonesian food patterns, } \\
\text { Indonesian food ingredients } \\
\text { Practices: Root-based staple foods, rice, corn, } \\
\text { from; Packed rice; Side dishes, meat dishes; } \\
\text { Fish dishes; Chicken dishes; Vegetable dishes } \\
\text { (group practice) } \\
\text { "Based on typical food from } 22 \text { provinces" }\end{array}$ & $\begin{array}{ll}\text { 1. } & \text { Recipe book } * \text { ) } \\
\text { 2. } & \text { Internet, } * * \text { ) } \\
\text { 3. } & \text { Modules } \\
\text { compiled by } \\
\text { supervisor } \\
\text { lecturers } * * *)\end{array}$ \\
\hline \multirow[t]{2}{*}{$\mathrm{A} 2$} & $\begin{array}{lr}\text { Indonesian } & \text { Food } \\
\text { Processing } & (3 \\
\text { credits }) & \end{array}$ & $\begin{array}{l}\text { Theory: Food Function, Basic Concepts of } \\
\text { Indonesian Food, Basic Concepts of Spices } \\
\text { and Indonesian Food Materials } \\
\text { Practices: Packed rice; Seasoned rice, animal } \\
\text { side dishes (meat); Animal side dishes } \\
\text { Poultry; Fish animal side dishes; Vegetable } \\
\text { side dishes; Vegetable dishes, sunday dishes; } \\
\text { Various soup, (group practice) } \\
\text { "Based on typical food from } 22 \text { provinces" }\end{array}$ & $\begin{array}{l}\text { 1. Internet } * \text { ) } \\
\text { 2. Recipe books } \\
* * \text { ) } \\
\text { 3. Modules } \\
\text { compiled by } \\
\text { supervisor } \\
\text { lecturers } * * *)\end{array}$ \\
\hline & $\begin{array}{l}\text { Indonesian } \\
\text { Specialties }\end{array}$ & $\begin{array}{l}\text { Theory: Describes dishes for special } \\
\text { occasions; Comparing the characteristics of } \\
\text { various special occasion dishes in different } \\
\text { parts of Indonesia through literature and } \\
\text { Analyzing special occasion dishes based on } \\
\text { life cycle from birth to death, and religious } \\
\text { ceremonies from } 24 \text { provinces in Indonesia. } \\
\text { Practice: Preparing and serving dishes for } \\
\text { special occasions based on life cycle (birth, } \\
\text { marriage, death, from } 7 \text { provinces in } \\
\text { Indonesia (group practice) }\end{array}$ & $\begin{array}{ll}\text { 1. } & \text { Lecturer } \\
\text { documents *) } \\
\text { 2. } \\
\text { Internet, } \\
\text { 3. } \begin{array}{l}\text { recipe book } \\
* * *)\end{array}\end{array}$ \\
\hline \multirow[t]{2}{*}{ A3 } & $\begin{array}{ll}\text { Indonesian } & \text { Food } \\
\text { Processing } & \end{array}$ & $\begin{array}{l}\text { Theory: The development of Indonesian food } \\
\text { in Industry; The characteristics of traditional } \\
\text { food in Indonesia; K3 in Indonesian food } \\
\text { practice; Principles of food safety in } \\
\text { Indonesian food } \\
\text { Practices: Sumatran Cuisine, East Java } \\
\text { Cuisine, Central Java, West Java, Jakarta; } \\
\text { Processing Kalimantan dishes; Processing } \\
\text { Sulawesi dishes; Processing dishes from } \\
\text { NTT, NTB, Bali; Processing ambon dishes, } \\
\text { Papua (consisting of; staple foods, side dishes, } \\
\text { and vegetable dishes); Processing of rice } \\
\text { dishes in leaves. (group practice) } \\
\text { "Based on typical food from } 22 \text { provinces" }\end{array}$ & $\begin{array}{l}\text { 1. } \begin{array}{l}\text { Lecturer } \\
\text { documents } * \text { ) }\end{array} \\
\text { 2. Recipe book } \\
* * \text { ) } \\
\text { 3. Standard } \\
\text { recipes } \\
\text { belonging to } \\
\text { institutions } \\
\text { that have been } \\
\text { tested } * * * \text { ) } \\
\text { 4. Internet } * * * *)\end{array}$ \\
\hline & ${ }_{\text {cake }}$ Nusantara & $\begin{array}{l}\text { Theory: the concept of the archipelago cake; } \\
\text { introduction to the variety of Indonesian } \\
\text { cakes; grouping types of archipelago cakes } \\
\text { based on processing techniques: steamed, } \\
\text { baked, fried, wrapped. } \\
\text { characteristics, and the basic ingredients of } \\
\text { Indonesian cakes consisting of: wheat flour, }\end{array}$ & $\begin{array}{ll}\text { 1. } & \begin{array}{l}\text { Lecturer } \\
\text { documents } * \text { ) }\end{array} \\
\text { 2. } & \text { Internet } * *) \\
\text { 3. } & \text { Recipe books } \\
& * * \text { ) }\end{array}$ \\
\hline
\end{tabular}




\begin{tabular}{|c|c|c|c|}
\hline & & $\begin{array}{l}\text { rice, rice flour, glutinous rice, glutinous rice } \\
\text { flour, cassava, sweet potatoes, bananas, corn, } \\
\text { hunkwe flour, } \\
\text { Practice: Processing wet cakes made from } \\
\text { rice, rice flour, sticky rice, glutinous rice } \\
\text { flour, wheat flour, hunkwe; Processing } \\
\text { various traditional hot and cold drinks; } \\
\text { Processing various traditional porridge (group } \\
\text { practice) } \\
\text { "Based on regional superiority" }\end{array}$ & \\
\hline \multirow[t]{2}{*}{ A4 } & $\begin{array}{lr}\text { Archipelago } & \text { Food } \\
\text { Processing } \\
\text { credits })\end{array}$ & $\begin{array}{l}\text { Theory: The concept of mapping regional } \\
\text { materials in Indonesia; Seasoning in } \\
\text { Indonesian food; Basic processing } \\
\text { techniques; basic spices, and the form of } \\
\text { serving archipelago food } \\
\text { Practices: Staple dishes of the archipelago; } \\
\text { Archipelago dishes; Soup, soup, and dishes } \\
\text { with Indonesian soup; Side dishes; Noodle } \\
\text { dishes; Vegetable dishes; Assorted chili } \\
\text { sauce, pickles, crackers (group). } \\
\text { International serving of archipelago dishes; } \\
\text { Creating formulas for Indonesian dishes } \\
\text { (creative Indonesian dishes), Creating recipes } \\
\text { for Indonesian dishes (individual) } \\
\text { "Based on typical food from } 20 \text { provinces" }\end{array}$ & $\begin{array}{l}\text { 1. } \begin{array}{l}\text { Lecturer } \\
\text { documents *) }\end{array} \\
\text { 2. Internet, recipe } \\
\text { books **) } \\
\text { 3. Standard } \\
\text { recipes } \\
\text { belonging to } \\
\text { institutions that } \\
\text { have been } \\
\text { tested for dioji } \\
* * *)\end{array}$ \\
\hline & $\begin{array}{l}\text { Traditional } \\
\text { Cake Processing } \\
(3 \text { credits })\end{array}$ & $\begin{array}{l}\text { Theory: The concept of traditional cakes } \\
\text { based on raw materials (rice, rice flour, sticky } \\
\text { rice, glutinous rice flour and flour; } \\
\text { Techniques for processing and serving } \\
\text { Indonesian cakes } \\
\text { Practice: Preparing and serving traditional } \\
\text { cakes based on the basic ingredients of rice, } \\
\text { rice flour, sticky rice, glutinous rice flour, and } \\
\text { flour. }\end{array}$ & $\begin{array}{ll}\text { 1. } & \text { Lecturer } \\
\text { documents } * \text { ) }\end{array}$ \\
\hline A5 & $\begin{array}{ll}\text { Indonesian } & \text { Food } \\
\text { Processing } & \end{array}$ & $\begin{array}{l}\text { Theory: Definition of archipelago food, } \\
\text { factors that influence archipelago mkn, } \\
\text { natural resource wealth and geographic } \\
\text { location J. and food classification J. West, J. } \\
\text { Middle, J. East. Sumatra, Kalimantan, NTT, } \\
\text { NTB, Bali, Sulawesi. } \\
\text { Practice: Processing dishes. } \\
\text { Practices: Processing and serving typical } \\
\text { food of North Sumatra, West Sumatra, Aceh, } \\
\text { South Sumatra, West Java, Central Java, East } \\
\text { Java, DKI Jakarta; Kalimantan, Sulawesi, } \\
\text { NTT, NTB, Bali, Maluku, Papua. (staple food, } \\
\text { side dishes, and vegetable dishes) (group } \\
\text { practice) } \\
\text { 'Based on regional superior dishes" }\end{array}$ & $\begin{array}{ll}\text { 1. } & \text { Lecturer } \\
\text { documents } * \text { ) }\end{array}$ \\
\hline
\end{tabular}




\begin{tabular}{|c|c|c|c|}
\hline & $\begin{array}{l}\text { O Indonesian } \\
\text { beverage and } \\
\text { cake processing }\end{array}$ & $\begin{array}{l}\text { Theory: Definition of cakes and drinks in } \\
\text { Indonesia, classification of cakes served at the } \\
\text { celebration ceremony (special occasions), } \\
\text { character of ingredients for making } \\
\text { Indonesian cakes } \\
\text { Practical: Able to process pastries and drinks } \\
\text { in all regions in Indonesia }\end{array}$ & 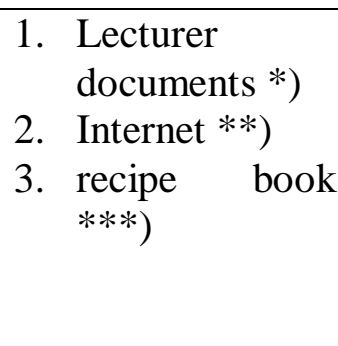 \\
\hline A6 & $\begin{array}{lr}\text { Indonesian } & \text { Food } \\
\text { Processing } & (3 \\
\text { credits }) & \end{array}$ & $\begin{array}{l}\text { Theory: Indonesian food raw materials; } \\
\text { Seasoning in Indonesian food; Basic } \\
\text { processing techniques and; form of serving } \\
\text { archipelago food } \\
\text { Practice: Indonesian staple food; Sepinggan } \\
\text { dish; archipelago soup; Side dishes; } \\
\text { Vegetable dishes (group practice). }\end{array}$ & $\begin{array}{l}\text { 1. } \begin{array}{l}\text { Lecturer } \\
\text { documents } * \text { ) }\end{array} \\
\text { 2. Internet } * *) \\
\text { 3. recipe book } \\
* * *)\end{array}$ \\
\hline & $\begin{array}{l}\text { Nusantara cake } \\
(3 \text { credits })\end{array}$ & $\begin{array}{l}\text { Theory: Introduction and characteristics of } \\
\text { ingredients for Indonesian cakes, introduction } \\
\text { to Indonesian cake processing techniques and } \\
\text { equipment, how to serve Indonesian cakes. } \\
\text { Practices: making Indonesian cakes, based on } \\
\text { ingredients: rice, rice flour, glutinous rice, rice } \\
\text { flour, wheat, and cassava from various regions } \\
\text { in Indonesia }\end{array}$ & $\begin{array}{l}\text { 4. } \begin{array}{l}\text { Lecturer } \\
\text { documents *) }\end{array} \\
\text { 5. Internet **) } \\
\text { 6. recipe book } \\
\text { ***) }\end{array}$ \\
\hline
\end{tabular}

Information: source of practicum material: *) most references, **) second reference, ***) 3rd reference

o) supporting courses "Indonesian Food"

The results of the study of the content of the course "Indonesian food", which is related to the material, reference sources can be seen through the table above, that the 6 Diploma 3 study programs in Indonesia, in principle, consist of theoretical courses given at the beginning of the lecture and continued with the practicum carried out in the culinary lab. Another course that supports the competence of "Indonesian food" is the course "kue nusantara" or "dishes for special occasions" which contains dishes that are usually served at ceremonies based on the life cycle, from birth to death ceremonies in Indonesia. The material for "Indonesian food" provided was relatively the same, namely dishes from various provinces in Indonesia based on dish groupings. Whereas on the other hand, regional specialties in Indonesia are very diverse and each has its own uniqueness. According to (Lazuardi \&
Triadi, 2015) the first traditional Indonesian cooking book was published in 1967, namely the Mustikarasa book which contains more than 1000 Indonesian recipes from Sabang to Merouke. Of course, with the passage of time until 2020, Indonesian specialties are increasingly diverse. This means that if students practice food throughout the archipelago with a maximum number of meetings of 7 to 12 for 300 minutes, then their skills to become professional cooks for "Indonesian food" are very doubtful. Supported by reference to the recipes that are practiced very minimal. None of the 6 culinary diploma programs have all the standard recipes that have been tested through research as ingredients or references that are given to students. From field observations, the recipes used by students during practice were obtained from tracking on the internet or searching through recipe books on the market which were consulted with the supervisor lecturers. There are only a few standard recipes that lecturers have obtained from the results of their training. This condition is linear with the statement 
of 6 members of the Indonesian Chef Association (ICA) through the FGD which was also attended by the supervisor of the "Indonesia food" course. The 6 ICA members already have long experience working as chefs in both hotels and restaurants. Some conclusions that can be conveyed regarding the competence of "Indonesian food" cooks are as follows: first, the skills possessed by Indonesian food restaurant cooks, especially in Malang, generally do not come from "educational products" but are inherited from parents who supported by work experience. Second, graduates of the culinary / culinary study program are considered to have insufficient expertise in processing "Indonesian Food" dishes, and will only increase their skills if they already have work experience and participate in handling "Indonesian food" in hotels or restaurants. Third, graduates of culinary school and the majority of Indonesian chefs have more expertise in oriental food and western food", because they do not get enough material or experience processing" Indonesian food "services in college. This condition is of course not in line with various studies which explain that vocational graduates must have skill assets, both skills according to their field of expertise and "generic" or soft skills such as communication skills and problemsolving skills to prepare for future jobs (Chang et al. , 2018) and (de Villiers Scheepers et al., 2018) (Sada et al., 2015) and (Ungaretti et al., 2015) in their research explain that the integration of the theory and practice of educational outcomes is important in order to align with the dynamic expectations of the job market. currently.

3. Learning methods

The quality of the results of vocational education in terms of processes and outcomes is strongly influenced by the appropriate learning approach or learning method, including the involvement of a practitioner from the relevant food industry. Based on the Vocational curriculum guide, it is explained that the implementation of vocational education will not run without collaboration with the business world and the industrial world (du / di) (Wardina et al., 2019). Supported by what is stated in the vocational curriculum guide (Research \& Higher, ND) which states that the curriculum in vocational higher education has the following characteristics: 1) Curriculum preparation involves associations, industry, and relevant stakeholders 2) curriculum content consists of subjects which emphasizes applied competence 3) curriculum development is carried out in accordance with the needs of the job market and industrial development. Following are the results of a study of the teaching method in the subject of "Indonesian food" which is supported by field observations, because the learning outcomes of specific subjects and course materials can be measured and observed up to the stage of the students' final ability in each subject.

Table 3. Learning methods, lecture time, and involvement of practitioners from Industry

\begin{tabular}{|c|c|c|c|c|c|c|}
\hline Activities & A1 & A2 & A3 & A4 & A5 & A6 \\
\hline \multirow{4}{*}{$\begin{array}{l}\text { Lecture } \\
\text { Theory: r } \\
\text { *) Method } \\
\text { Learning } \\
\text { **) the } \\
\text { learning } \\
\text { time used }\end{array}$} & *) & *) & Lecture & *) & *) & *) \\
\hline & $\begin{array}{l}\text { lectures, } \\
\text { discussion }\end{array}$ & $\begin{array}{l}\text { lectures, } \\
\text { discussion }\end{array}$ & $\begin{array}{l}\text { (brain } \\
\text { storming), }\end{array}$ & $\begin{array}{l}\text { lectures, } \\
\text { discussion }\end{array}$ & $\begin{array}{l}\text { lectures, } \\
\text { discussion }\end{array}$ & $\begin{array}{l}\text { lectures, } \\
\text { discussion }\end{array}$ \\
\hline & $\begin{array}{l}\text { s and } \\
\text { assignme } \\
\text { nts. } \\
* *)\end{array}$ & $\begin{array}{l}\mathbf{S} \quad \text { and } \\
\text { assignme } \\
\text { nts. } \\
* *)\end{array}$ & $\begin{array}{l}\text { discussion, } \\
\text { Problem } \\
\text { Based } \\
\text { Learning }\end{array}$ & $\begin{array}{l}\text { s, PBL } \\
\text { and } \\
\text { assignme } \\
\text { nts. }\end{array}$ & $\begin{array}{l}s \quad \text { and } \\
\text { assignme } \\
\text { nts. }\end{array}$ & $\begin{array}{l}s \quad \text { and } \\
\text { assignmen } \\
\text { ts.. }\end{array}$ \\
\hline & & & $\begin{array}{l}(\mathrm{PBL}) . \\
* *)\end{array}$ & $* *)$ & $* *)$ & $* *)$ \\
\hline
\end{tabular}




\begin{tabular}{|c|c|c|c|c|c|c|}
\hline & $\begin{array}{l}5 \text { meeting } \\
x \quad 100 \\
\text { minute }\end{array}$ & $\begin{array}{l}3 \text { meeting } \\
x \quad 300 \\
\text { minute }\end{array}$ & $\begin{array}{l}5 \text { meeting } x \\
250 \text { minute }\end{array}$ & $\begin{array}{l}5 \text { meeting } \\
x \quad 200 \\
\text { minute }\end{array}$ & $\begin{array}{l}7 \text { meeting } \\
x \quad 100 \\
\text { minute }\end{array}$ & $\begin{array}{l}4 \text { meeting } \\
x \quad 200 \\
\text { minute }\end{array}$ \\
\hline $\begin{array}{l}\text { Practical } \\
\text { lecture } \\
\text { *) Method } \\
\text { **) Time } \\
\text { used }\end{array}$ & $\begin{array}{l}* \text { *) Lab } \\
\text { practice } \\
\\
* *) \quad 9 \\
\text { meetings } \mathrm{x} \\
200 \text { ' }\end{array}$ & $\begin{array}{l}* \text { Lab } \\
\text { practice } \\
* *) 10 \\
\text { meeting } \mathrm{x} \\
300^{\circ}\end{array}$ & $\begin{array}{l}\text { *) } \\
\text { Demonstrati } \\
\text { on, } \\
\text { performance } \\
\text { test / lab } \\
\text { practice } \\
\text { **) } \\
\text { meeting } 10 \\
250^{6}\end{array}$ & \begin{tabular}{|lr}
$*)$ & Lab \\
practice & \\
& \\
$* *)$ & 9 \\
meeting & $\mathrm{x}$ \\
300 &
\end{tabular} & $\begin{array}{ll} & \\
* *) & 7 \\
\text { meeting } & \mathrm{x} \\
150^{6} & \end{array}$ & $\begin{array}{l}* \text { practice } \\
\text { prab } \\
* *) 10 \\
\text { meeting } \\
\text { X } 300^{\circ}\end{array}$ \\
\hline $\begin{array}{l}\text { Time for } \\
\text { Theory } \\
\text { and } \\
\text { Practice } \\
\text { Exams }\end{array}$ & $\begin{array}{l}\text { Theory : } 2 \\
\text { x } 50 \text { ‘ } \\
\text { Practice } 6 \\
x 50^{\circ}\end{array}$ & $\begin{array}{l}\text { Theory : } 2 \\
x 50{ }^{\circ} \\
\text { Practice } k \\
6 \times 50^{،}\end{array}$ & $\begin{array}{l}\text { Theory : } 2 \\
\text { x } 50 \text { ‘ } \\
\text { Practice } 6 \mathrm{x} \\
50^{\circ}\end{array}$ & $\begin{array}{l}\text { Theory : } 2 \\
\text { x } 50^{`} \\
\text { Practice } 6 \mathrm{x} \\
50^{\circ}\end{array}$ & $\begin{array}{l}\text { Theory : } 2 \\
\text { x } 50 \text { ‘ } \\
\text { Practice } 6 \mathrm{x} \\
50^{\circ}\end{array}$ & $\begin{array}{l}\text { Theory : } 2 \\
\text { x } 50^{\circ} \\
\text { Practice } 6 \mathrm{x} \\
50^{\circ}\end{array}$ \\
\hline $\begin{array}{l}\text { Waktu } \\
\text { yang } \\
\text { digunakan } \\
\text { untuk mata } \\
\text { kuliah } \\
\text { "Indonesia } \\
\text { n Food" } \\
\text { selama 1 } \\
\text { semester }\end{array}$ & $\begin{array}{l}2700 \\
\text { minutes }\end{array}$ & $\begin{array}{l}4300 \\
\text { minutes }\end{array}$ & $\begin{array}{l}3750 \\
\text { minutes }\end{array}$ & $\begin{array}{l}4100 \\
\text { minutes }\end{array}$ & $\begin{array}{l}2150 \\
\text { minutes }\end{array}$ & $\begin{array}{l}4200 \\
\text { minutes }\end{array}$ \\
\hline $\begin{array}{l}\text { Presentase } \\
\text { Perbandin } \\
\text { gan kuliah } \\
\text { teori : } \\
\text { praktek : } \\
\text { time is not } \\
\text { used }\end{array}$ & $\begin{array}{l}12,5 \quad: \\
43,75: 22,9 \\
1\end{array}$ & $\begin{array}{l}20 \quad: \\
68,75: 10,4 \\
1\end{array}$ & $\begin{array}{l}26: 52,08: \\
21,87\end{array}$ & $\begin{array}{l}22,91 \\
: 64,59 \\
12,5\end{array}$ & $\begin{array}{l}16,66 \\
28,13 \\
55,20\end{array}$ & \begin{tabular}{|l|}
18,75 \\
68,75 \\
12,5
\end{tabular} \\
\hline $\begin{array}{l}\text { Availabilit } \\
y \quad \text { of } \\
\text { modules / } \\
\text { teaching } \\
\text { materials } \\
\text { prepared } \\
\text { by } \\
\text { supervisor } \\
\text { lecturers }\end{array}$ & $\begin{array}{l}\text { Module: } \\
\text { Indonesia } \\
\text { n Food } \\
\text { Knowledg } \\
\text { e }\end{array}$ & $\begin{array}{l}\text { Indonesia } \\
\text { n Food } \\
\text { Processin } \\
\text { g }\end{array}$ & $\begin{array}{l}\text { Indonesia } \\
\text { n } \quad \text { Food } \\
\text { Processing }\end{array}$ & $\begin{array}{l}\text { Readers } \\
\text { Indonesia } \\
\mathrm{n} \quad \text { Food } \\
\text { Processin } \\
\mathrm{g}\end{array}$ & $\begin{array}{l}\text { Module: } \\
\text { Indonesia } \\
\text { n cuisine } \\
\text { from } \\
\text { Sabang to } \\
\text { Merauke }\end{array}$ & $\begin{array}{l}\text { Collection } \\
\text { of } \\
\text { Indonesia } \\
\text { n recipes }\end{array}$ \\
\hline $\begin{array}{l}\text { Structured } \\
\text { Assignme } \\
\text { nts / Tasks }\end{array}$ & $\begin{array}{l}\text { Papers on } \\
\text { foodstuffs } \\
\text { in } \\
\text { Indonesia }\end{array}$ & $\begin{array}{l}\text { Indonesia } \\
\mathrm{n} \text { culinary } \\
\text { paper }\end{array}$ & $\begin{array}{l}\text { Resume of } \\
\text { discussion } \\
\text { results on } \\
\text { each } \\
\text { "theory" } \\
\text { material }\end{array}$ & $\begin{array}{l}\text { Concept } \\
\text { paper and } \\
\text { diet in } \\
\text { Indonesia }\end{array}$ & $\begin{array}{l}\text { Indonesian } \\
\text { dish paper }\end{array}$ & $\begin{array}{l}\text { Clippings } \\
\text { of a } \\
\text { collection } \\
\text { of } \\
\text { Indonesian } \\
\text { recipes }\end{array}$ \\
\hline
\end{tabular}




\begin{tabular}{|c|c|c|c|c|c|c|}
\hline $\begin{array}{l}\text { Involveme } \\
\text { nt of } \\
\text { industry } \\
\text { practitione } \\
\text { rs (1st to } \\
16 \text { th pert. } \\
\text { D to 16) }\end{array}$ & Nothing & Nothing & Nothing & Nothing & Nothing & Nothing \\
\hline $\begin{array}{l}\text { Industrial } \\
\text { visits } \\
\text { (especially } \\
\text { for } \\
\text { Indonesian } \\
\text { food) }\end{array}$ & Nothing & Nothing & Nothing & Nothing & Nothing & Nothing \\
\hline
\end{tabular}

According to (Jabarullah \& Hussain, 2019) The learning process of students is required to use appropriate and effective learning methods, therefore the selection of learning methods must be adjusted to the learning outcomes that have been determined and the characteristics of each course. The recommended learning methods (Research \& Higher, ND) in each subject can be: group discussions, simulations, case studies, collaborative learning, cooperative learning, project-based learning, problembased learning, or other learning methods that can effectively facilitate fulfillment of graduate learning outcomes. Each subject can use one or a combination of several learning methods in the hope that the expected abilities that have been established in a learning stage will be achieved by the selected learning method / model.

The learning methods used in the "Indonesian food" course at 6 tertiary institutions are almost the same. The first material to the 4th (there is until the 7 th meeting), namely the provision of theories on the concept of Indonesian food, introduction to ingredients, spices and others. The method used to deliver $80 \%$ theoretical lectures is still using the lecture method using Liquid Crystal Display (LCD) media followed by discussions and assignments. As for practicum lectures, students in groups directly practice cooking according to the theme of the material based on agreement (consultation) with the supervisor. Practicum is carried out in groups with an average of 1 group consisting of 3 to 4 people. But in doing so they have their own responsibility. For example, in the theme of soto dishes, the A does the Soto typical of the Madura region, the B does the typical Soto for the Banjar area, and the $\mathrm{C}$ does the typical Soto for the Bandung area. So it is possible even though in one group they only master 1 type of soup. This means that the mastery of the material obtained from practical experience is different from one another. Evaluation of practical results includes: organoleptic results (taste, aroma, texture) and presentation. If the results do not meet the requirements, no remedial is done, so that a standard recipe is not obtained from the results of student practicum.

Based on (Education \& Number, 49) higher education academic provisions, that the determination of SKS. For theoretical courses, practical courses, and field courses are set as follows: theory course 1 credit $=$ $1 \mathrm{JS}$, practical lecture $1 \mathrm{SKS}=2 \mathrm{JS}$, and field course 1 credit $=4$ JS. Other provisions stated $1 \mathrm{JS}=50$ minutes face to face. The number of credits for the "Indonesian food" course in 6 universities is the same, namely ( 3 credits / 6 JS), which is equivalent to 16 meetings $\times 6 \times 50$ minutes $=4800$ minutes. implement the above rules, whether face-to-face meeting theory, practice, or weight assignment. The percentage of face-to-face theory and practice is relatively in accordance with the 
vocational education curriculum guidelines (Research \& Higher, N.D.), which must put more emphasis on practicum in order to train student skills. (Horng \& Hu, 2008). explained that the accuracy of the composition between practice and supporting theory is the key to the successful implementation of the educational process in culinary education. The composition of practice is more dominant than theory is the hallmark of culinary education. However, as can be seen in table 3 based on the observations on the RPP, the time used for face-to-face implementation, either theoretically or practically, in the 6 Culinary Diploma programs, none of which is in accordance with the rules (Research \& Higher, N.D.). The time wasted is between $10.41 \%$ and $55.20 \%$. This of course will have an impact on the mastery of material possessed by students.

The involvement of guest lecturers or extraordinary lecturers from the relevant industry (Indonesian food chef) has never been done, even though one of the characteristics of vocational education is that it must always involve practitioner lecturers from the industry from curriculum preparation to the learning process, especially for culinary education. continues to experience changes and developments.
As stated in the Law No. 12/2012 (No. 12), the explanation of article 16 paragraph 1 states that education that prepares students to become professionals with high work abilities must be prepared together with the professional community and professional organizations that are responsible for the organization for the quality of their professional services. .

4. The Expertise of Advisory Lecturers for the "Indonesian Food" Course

One of the keys to the success of higher education is the competence of the lecturers. Lecturer is one of the essential components in the education system in higher education. The importance of increasing the continuous professional competence of vocational lecturers has not been fully realized by lecturers and leaders in vocational higher education institutions. perfecting these three activities. As explained by (Hoekstra \& Crocker, 2015) that lecturers in vocational education are required to have special professional competences so that the output produced by educational institutions can be useful outcomes for the community in accordance with the objectives of providing vocational education. The following are the competencies / expertise of lecturers based on educational background, training, and work experience.

Table 4. Advisory Expertise based on educational background, training and work experience.

\begin{tabular}{|c|c|c|c|c|c|c|}
\hline $\begin{array}{l}\text { Competen } \\
\text { cies of } \\
\text { Lecturers }\end{array}$ & A1 & A1 A2 & A3 & A4 & A A5 & A6 \\
\hline $\begin{array}{l}\text { Education } \\
\text { al } \\
\text { backgroun } \\
\text { d }\end{array}$ & $\begin{array}{l}\text { S1 : PKK } \\
\text { IKIP } \\
\text { Bandung } \\
\text { S2 } \\
\text { Vocationa } \\
1 \\
\text { Education } \\
\text { (PKJ) }\end{array}$ & $\begin{array}{l}\text { S1 : PKK } \\
\text { IKIP } \\
\text { Jakarta } \\
\text { S2 : PKJ } \\
\text { S3 : Food } \\
\text { Technology } \\
\text { (THP) }\end{array}$ & $\begin{array}{l}\text { S1 : PKK } \\
\text { IKIP Jogja } \\
\text { S2 : PKJ }\end{array}$ & $\begin{array}{l}\text { S1 : PKK } \\
\text { IKIP } \\
\text { Jakarta } \\
\text { S2 : } \\
\text { Keahlian } \\
\text { Gizi } \\
\text { Masyarak } \\
\text { at }\end{array}$ & $\begin{array}{l}\text { S1 : PKK } \\
\text { IKIP } \\
\text { Makasar } \\
\text { S2 : PKJ } \\
\text { S3 : PKJ }\end{array}$ & $\begin{array}{l}\text { \$1: PKK } \\
\text { IKIP } \\
\text { Padang } \\
\text { s2: PKJ }\end{array}$ \\
\hline $\begin{array}{l}\text { Indonesian } \\
\text { Food } \\
\text { training } \\
\text { that has }\end{array}$ & Never & Never & $\begin{array}{l}\text { - Year } \\
\text { 1987: } \\
\text { Indonesia } \\
\text { n Cuisine } \\
\text { for }\end{array}$ & Never & $\begin{array}{l}\text { Year } \\
\text { 2000: } \\
\text { Training } \\
\text { on various }\end{array}$ & Never \\
\hline
\end{tabular}




\begin{tabular}{|c|c|c|c|c|c|c|}
\hline $\begin{array}{l}\text { been } \\
\text { attended }\end{array}$ & & & $\begin{array}{l}\text { catering } \\
\text { business } \\
-\quad \text { Year } \\
\text { 1989: } \\
\text { food in the } \\
\text { style of } \\
\text { the Jogya } \\
\text { palace }\end{array}$ & & $\begin{array}{l}\text { traditional } \\
\text { cakes }\end{array}$ & \\
\hline $\begin{array}{l}\text { Experienc } \\
\text { e teaching } \\
\text { "Indonesia } \\
\text { n food" }\end{array}$ & $\begin{array}{ll}1992- \\
\text { present }\end{array}$ & $\begin{array}{l}1990 \\
\text { present }\end{array}$ & $\begin{array}{l}1987- \\
\text { present }\end{array}$ & $\begin{array}{l}1988- \\
\text { present }\end{array}$ & $\begin{array}{l}1999 \\
\text { present }\end{array}$ & $\begin{array}{l}1989 \\
\text { present }\end{array}$ \\
\hline $\begin{array}{l}\text { Pengalama } \\
\text { n kerja di } \\
\text { Usaha } \\
\text { Boga }\end{array}$ & No & No & No & No & No & No \\
\hline $\begin{array}{l}\text { Research } \\
\text { experience } \\
\text { on } \\
\text { "Indonesia } \\
\text { n Food" }\end{array}$ & Never & $\begin{array}{l}\text { Multi years } \\
\text { "Tengger } \\
\text { specialties } \\
\text { *) has not } \\
\text { been } \\
\text { applied to } \\
\text { the } \\
\text { "Indonesian } \\
\text { food" } \\
\text { course }\end{array}$ & Never & $\begin{array}{l}2013- \\
2014 \\
\text { research } \\
\text { on Soto } \\
\text { Nusantara } \\
\text { and side } \\
\text { dishes } \\
\text { *) has } \\
\text { become a } \\
\text { standard } \\
\text { student } \\
\text { practicum }\end{array}$ & never & Never \\
\hline $\begin{array}{l}\text { Aqcquisiot } \\
\text { ion of } \\
\text { "Indonesia } \\
\text { n Food" }\end{array}$ & $\begin{array}{l}- \text { Outodida } \\
\mathrm{k} \\
\text { - Parents } \\
\text { - Recipe } \\
\text { books }\end{array}$ & - Outodidak & $\begin{array}{l}\text { - Outodida } \\
\text { k } \\
\text { - Industry } \\
\text { survey } \\
\text { - Test } \\
\text { recipe }\end{array}$ & $\begin{array}{l}\text { - Outodida } \\
\text { k } \\
\text { Recipe } \\
\text { books } \\
\text { Standar } \\
\text { Research } \\
\text { result }\end{array}$ & $\begin{array}{l}- \text { Outodida } \\
\mathrm{k} \\
\text { - Parents } \\
\text { - Recipe } \\
\text { books }\end{array}$ & $\begin{array}{l}\text { - Outodid } \\
\text { ak } \\
\text { - Parents } \\
\text { - Recipe } \\
\text { books }\end{array}$ \\
\hline
\end{tabular}

Based on table 4 , it can be seen that the expertise of the "Indonesian food" supervisory lecturer in terms of educational background, the majority have an undergraduate education background (S1) Family Welfare Education with the minor program Tata Catering Institute of Teacher Training and Education (IKIP) which has now changed functions since 20 years ago it became a university. The S2 and S3 education that is taken is vocational education which in the curriculum does not touch at all about "Indonesian Food" expertise. Likewise with Food Product
Technology (THP) and public nutrition graduates. Lecturers in vocational education are required to have special professional competences so that the output produced by educational institutions can be beneficial outcomes for the community (Hoekstra \& Crocker, 2015). Thus it can be concluded that the conditions of the lecturers of the Catering Diploma program at the TTIs are currently still heterogeneous, both in terms of unsuitable academic qualifications and competence. In order to address this gap, it is necessary to anticipate and implement policy strategies 
in proper planning and structuring as well as comprehensive so that the direction of development and fostering of Culinary Diploma education lecturers is more focused in order to prepare graduates who are ready to work, especially as cook for "Indonesian food". professional. So one solution is to comply with the Law of the Republic of Indonesia Number 12 of 2012, namely that a standard of vocational lecturers is required, especially in the culinary field. Vocational lecturers must have an educational background for an applied master program or a liner applied doctoral program. At least have expertise through training or work experience in their field. The development of sustainable professional competence for vocational lecturers is indispensable for the 21st century, when the life of the 21 st century is determined by knowledge and service or known as a knowledge-based economy. This is consistent with research conducted by (Hegde, 2013) and (Pimlott, 2014) which states that "Continuing professional development (CPD)" is an important element in lifelong learning strategies.

Based on the results of the FGD with 6 heads of the Culinary Diploma study program, 6 cooks for "Indonesian Food" from ICA members, and 6 supervisors for the "Indonesian food" course, it was agreed that curriculum revitalization and content review of the content of the "Indonesian food" course would be carried out, and increase the content of the course "regional food" according to where the college is located as local content. In the "regional food" course, skills in processing and serving regional food will be given deeper and more focus on developing their own regional culinary culture. In addition, it is advisable to develop a prototype "textbook" for regional specialties, which is equipped with tried and standard recipes.

\section{Conclusion}

Overall the results of this study indicate that the implementation of the curriculum in the subject content of "Indonesian Food" in the 6 LPTK Diploma programs in Indonesia has not paid attention to the policies and regulations that apply and are contained in the book "Guidelines for vocational curriculum preparation". Several findings that were deemed unsuitable include: 1) The content of Indonesian food material is still general. All local specialties from 34 provinces are practiced so that students' skills are not focused and not deep. The references used are still limited to recipe books, internet tracking, and there are no standard recipes based on trials or research results from supervisors. 2) the theoretical learning method still uses the lecture method using 1 media (LCD). Whereas food processing practice, direct practice in the production lab refers to the job sit that has received approval from the supervisor. Practice is done in groups. So that the abilities of the participants differ from each other. 3) Not involving practitioners from Industry in the learning process. 4) The advisory lecturer expertise is not linear with the subjects being taught.

Based on the FGD with related parties, it is agreed that the graduates of the Diploma 3 Catering Program in Indonesia are not ready to become professional "Indonesian Food" cooks, one of the indicators of which is the inappropriate application of the curriculum. So it was agreed to make arrangements that involved: 1) revitalizing the culinary diploma curriculum, 2) Reviewing the content of the "Indonesian Food" course, 3) Improving the skills of lecturers through training and research leading to the processing of "Indonesian food" 4) Compiling the book "Indonesian Food "which leads to education based on local wisdom, which can facilitate students to know, get to know, and have cooking skills and to serve dishes which are the hallmarks of the regions where they follow their education.

\section{Reference}


[1] Anggraini, M. (2018). Gastrodiplomasi sebagai strategi pengembangan pariwisata kuliner Indonesia dalam mendukung program ASTP. Seminar Nasional Dan Diskusi Panel Multidisiplin Hasil Penelitian Dan Pengabdian Kepada Masyarakat 2018, 1(1).

[2] Byrnes, N. K., Loss, C. R., \& Hayes, J. E. (2015). Perception of chemesthetic stimuli in groups who differ by food involvement and culinary experience. Food Quality and Preference, 46, 142-150.

[3] Chang, J.-C., Hsiao, Y.-D., Chen, S.C., \& Tsung-Ta, Y. (2018). Core entrepreneurial competencies of students in departments of electrical engineering and computer sciences (EECS) in universities. Education+ Training.

[4] de Villiers Scheepers, M. J., Barnes, R., Clements, M., \& Stubbs, A. J. (2018). Preparing future-ready graduates through experiential entrepreneurship. Education+ Training.

[5] Hanafi, I. (2012). Re-orientasi keterampilan kerja lulusan pendidikan kejuruan. Jurnal Pendidikan Vokasi, 2(1).

[6] Harmayani, E., Santoso, U., \& Gardjito, M. (2019). Makanan Tradisional Indonesia Seri 1: Kelompok Makanan Fermentasi dan Makanan yang Populer di Masyarakat. UGM PRESS.

[7] Hegde, P. (2013). Faculty Development Trends in Medical Education. South East Asian Journal of Medical Education, 7(2), 11.

[8] Hoekstra, A., \& Crocker, J. R. (2015). Design, implementation, and evaluation of an ePortfolio approach to support faculty development in vocational education. Studies in Educational Evaluation, 46, 61-73.

[9] Horng, J.-S., \& Hu, M.-L. (2008). The mystery in the kitchen: Culinary creativity. Creativity Research Journal, 20(2), 221-230.

[10] Jabarullah, N. H., \& Hussain, H. I. (2019). The effectiveness of problembased learning in technical and vocational education in Malaysia. Education+ Training.

[11] Lazuardi, M., \& Triadi, M. S. (2015). Rencana Pengembangan Kuliner Nasional 2015-2019. PT. Republik Solusi.

[12] Mariana, R., Nurjanah, N., \& Dardiri, A. (2018). Competence Profile of Indonesian Food Chefs in Malang Based on Educational Background. International Conference on Indonesian Technical Vocational Education and Association (APTEKINDO 2018).

[13] Musanna, A. (2010). Revitalisasi Kurikulum Muatan Lokal untuk Pendidikan Karakter Melalui Evaluasi Responsif. Jurnal Pendidikan Dan Kebudayaan, 16(9), 245-255.

[14] Nasional, D. P., Cipta, R., Soemanto, W., Pendidikan, P., Somantri, M. N., Rosada, R., JR, S. A., Karakter, P. N.N., Persada, P. R., \& Muammad, Y. (2003). Undang-Undang. Sistem Pendidikan Nasional.

[15] Ndou, V., Mele, G., \& Del Vecchio, P. (2019). Entrepreneurship education in tourism: An investigation among European Universities. Journal of Hospitality, Leisure, Sport \& Tourism Education, 25, 100175.

[16] Nomor, U.-U. R. I. (12). Tahun 2012 tentang Pendidikan Tinggi.

[17] Pearson, D., \& Pearson, T. (2016). Branding food culture: UNESCO creative cities of gastronomy. Journal of International Food \& Agribusiness Marketing, 28(2), 164-176.

[18] Pendidikan, P. M., \& Nomor, K. R. I. (49). Tahun 2014 tentang Standar Nasional Pendidikan Tinggi. Peraturan Presiden Nomor, 8.

[19] Pimlott, N. (2014). Supporting continuing professional development. 
The College of Family Physicians of Canada.

[20] Rauch, A., \& Hulsink, W. (2015). Putting entrepreneurship education where the intention to act lies: An investigation into the impact of entrepreneurship education on entrepreneurial behavior. Academy of Management Learning \& Education, 14(2), 187-204.

[21] RISET, K., \& TINGGI, T. D. P. (n.d.). Panduan Penyusunan Kurikulum Pendidikan Vokasi.

[22] Sada, A. M., Mohd, Z. A., Adnan, A., \& Audu, R. (2015). Effects of problem-based learning in teaching and learning of technical and vocational education and training. International Journal of Scientific and Research Publications, 5(5), 1-3.

[23] Scarpetta, S., Sonnet, A., Livanos, I., Núñez, I., Riddell, W. C., Song, X., \& Maselli, I. (2012). Challenges facing European labour markets: Is a skill upgrade the appropriate instrument? Intereconomics, 47(1), 4-30.

[24] Triyono, M. B. (2017). Tantangan revolusi industri Ke 4 (I4. 0) bagi pendidikan vokasi. Proceeding Semnasvoktek, 2, 1-5.

[25] Ungaretti, T., Thompson, K. R., Miller, A., \& Peterson, T. O. (2015). Problem-based learning: Lessons from medical education and challenges for management education. Academy of Management Learning \& Education, 14(2), 173186.

[26] Wardina, U. V., Jalinus, N., \& Asnur, L. (2019). Kurikulum Pendidikan Vokasi Pada Era Revolusi Industri 4.0. Jurnal Pendidikan, 20(1), 82-90.

[27] Yi, L. (2016). The sense of Chengdu: Embodied heritage in tastescape $[\mathrm{PhD}$ Thesis]. 